\title{
Chemical composition, phytochemical and mineral profile of garlic (Allium sativum)
}

\author{
Yusuf, Abayomi ${ }^{1}$, Fagbuaro, S. S..$^{\star}$ and Fajemilehin, S. O. K. ${ }^{2}$ \\ ${ }^{1}$ Department of Agriculture, College of Education (Technical) Lafiagi, Kwara State, Nigeria. \\ 2Department of Animal Science, Faculty of Agricultural Sciences Ekiti State University, Ado-Ekiti, Nigeria. \\ ${ }^{*}$ Correspondence author. Email: dipofajemilehin@yahoo.com
}

Copyright $(2018$ Fagbuaro et al. This article remains permanently open access under the terms of the Creative Commons Attribution License 4.0, which permits unrestricted use, distribution, and reproduction in any medium, provided the original work is properly cited.

Received 31st May, 2018; Accepted 20th June, 2018

\begin{abstract}
The practice of complementary and alternative medicine is now on the increase in developing countries in response to World Health Organization's directives. This has culminated in several pre-clinical and clinical studies that have provided the scientific basis for the efficacy of many plants used in folk medicine to improve growth performance in farm animals and treat infections. This study was carried out to investigate the chemical, mineral and phytochemical contents of garlic as a preliminary work to evaluate the influence of garlic on the performance characteristics of broiler chickens. Garlic bulbs (Allium sativum), including cloves and hulls, were obtained from the open market at Ado-EkitiNigeria. The garlic bulbs were desegmented into cloves and were cut into chips. The chips were sun-dried for 3 weeks. The dried garlic chips were milled and analysed for the chemical compositions. The results obtained indicated that garlic on dry matter basis contained $4.55 \mathrm{mg} / 100 \mathrm{~g}, 73.22 \mathrm{mg} / 100 \mathrm{~g}$ and $15.33 \mathrm{mg} / 100 \mathrm{~g}$ of moisture, carbohydrate and crude protein respectively. The crude fat was $0.72 \mathrm{mg} / 100 \mathrm{~g}$ while crude fibre and ash were $2.10 \mathrm{mg} / 100 \mathrm{~g}$ and $4.08 \mathrm{mg} / 100 \mathrm{~g}$, respectively. Garlic contained $10.19,26.30,10.19,5.29,0.001,0.34$ and $0.001 \mathrm{mg} / 100 \mathrm{~g}$ of potassium, calcium, phosphorus, iron, magnesium, zinc and manganese respectively while lead and cobalt were below detection level. Garlic is acidic $(\mathrm{pH}=3.91)$ and contained $4.21,3.54,0.64,0.80,5.56,0.04$ and $0.02 \mathrm{mg} / 100 \mathrm{~g}$ of alkaloids, tannins, carotenoids, saponin, flavonoids, steroids and cardenolides, respectively. Garlic as a feed additive possesses nutritional properties for use in the enhancement of improved livestock production.
\end{abstract}

Key words: Garlic bulbs, phytochemical content, $\mathrm{pH}$, proximate composition, mineral contents.

\section{INTRODUCTION}

Garlic is a vegetable plant, a bulb belonging to the family Liliaceae. It is a widely distributed plant grown globally and China is the leading producer with over $81 \%$ of world output (Lewis, 2012). Garlic is the most important preventive herb, a spice, a well-trusted remedy during the various epidemics such as dysentery, typhoid, cholera and influenza (Topak and Mozaik, 2005). It is an effective remedy for a variety of ailments (Kishu, 2009). Garlic contains at least 100 sulphur-containing compounds basic to medicinal uses with Allicin representing 70 to 80 percent of the total thiosulphinates found in it (Kishu. 2009). It has a slight, imperceptible smell until it has been peeled. Once peeled, sliced or crushed, it immediately begins to spread an intense smell that contains sulphur glycosides. Many studies have indicated that allicin is the most important component of garlic that is responsible for its characteristic odour, flavour as well as most of its biological properties (Chowdhury et al., 2002; Durak et al., 2002; Heinrich et al., 2004; Shalaby et al., 2006).

Despite its high medicinal and culinary value, garlic contains some anti-nutritional factors such as flavonoids, saponin, tannin, alkaloids, steroids, hydrocyanide and anthocyanin (Okaka and Okaka., 2001). Flavonoids, saponins and tannin contents of garlic are within the range of 0.04 to $0.36 \%, 0.14$ to $19.0 \%$, and 0.06 to $6.10 \%$, respectively (Friday et al., 2011). 
Although uncommon, allergic reactions to garlic have been reported with various symptoms such as difficult breath, closing of the throats and swelling of the lips, tongue or face. Other symptoms especially in raw garlic consumption include burning of the mouth, throat and stomach, diarrhoea, sweating, nausea or vomiting, light headedness, eczema or a rash, redness/swelling/blistering when applied to the skin, easy bruising or bleeding (nosebleed, bleeding gums), unpleasant breath or body odour (Borek, 2005).

The practice of complementary and alternative medicine is now on the increase in developing countries in response to World Health Organization's directives. This has culminated to several pre-clinical and clinical studies that have provided the scientific basis for the efficacy of many plants used in folk medicine to treat infections (Dilhuydy, 2003 and Iwalokun et al., 2004). Garlic Agronomy (2009) reported that the composition of garlic bulb is approximately $85.09 \%$ water, $13.38 \%$ organic matter and $1.53 \%$ inorganic matter while the leaf is $87.14 \%$ water, $11.27 \%$ organic matter and $1.59 \%$ inorganic matter. Researchers were not unanimous on the quantum of chemical and phytonutrient contents of this important herb. Therefore, this study was carried out to characterize the commercial garlic with respect to its proximate, mineral and phyto-chemical constituents.

\section{MATERIALS AND METHOD}

Garlic bulbs (Allium sativum) were purchased from the open market at Ado Ekiti, Ekiti State, Nigeria. The garlic bulbs were desegmented into cloves and cut into chips. The chips were sun-dried for 3 weeks. The dried garlic chips were milled and analyzed for chemical and proximate composition as described in AOAC (2000) Method No. 984-13.

The sodium and potassium contents were determined by flame photometry while phosphorus was determined by the vanado-molybdate method (AOAC 2000). The other mineral elements were determined after wet digestion with a mixture of nitric, sulphuric and hydrochloric acid using Atomic Absorption Spectrophotometer (AAS model Spq).

The anti-nutritional factors were determined as follows: Saponin was quantified according to the procedure of Obadoni and Ochuko (2001). Tannin was calculated using the relationship described by Van- Burden and Robinson (1981):

$\%$ Tannin $=\frac{100 \times \mathrm{AU} \times \mathrm{VF} \times \mathrm{D}}{\mathrm{W} \times \mathrm{AS} \times \mathrm{VA}}$

where, $\mathrm{W}=$ weight of sample analyzed, $\mathrm{AU}=\mathrm{Absorbance}$ of standard tannin solution, $A S=$ Concentration $(\mathrm{mg} / \mathrm{ml})$ of standard tannin solution, VF = Total volume of filtrate, VA = volume of filtrate analyzed, $\mathrm{D}=$ dilution factor.
The method of Harbone (1973) was used for the alkaloids quantification while flavonoid was quantified using Boham and Kocipai-Abyazan (1994) method:

$\%$ Flavonoids $=\frac{100(\mathrm{~W} 2-\mathrm{W} 1)}{\text { Weight of Sample }}$

Where, $\mathrm{W} 1$ = weight of empty crucible, $\mathrm{W} 2=$ weight of crucible + Flavonoid precipitate.

The $\mathrm{pH}$ was determined by making garlic paste with citric acid in $10 \%$ solution of sample and the $\mathrm{pH}$ was measured by inserting a pH meter (Model L. Pulse Muchen 15-1260, Germany).

\section{RESULTS AND DISCUSSION}

Table 1 shows the proximate composition of garlic. The result indicated that garlic powder on dry matter basis contained $4.55,73.22$ and $15.33 \mathrm{mg} / 100 \mathrm{~g}$ of moisture, carbohydrate and crude protein, respectively. The crude fat was $0.72 \mathrm{mg} / 100 \mathrm{~g}$ while crude fibre and ash were 2.10 and $4.08 \mathrm{mg} / 100 \mathrm{~g}$, respectively. Garlic contained appreciable amounts of carbohydrates and protein suggesting that it can be ranked as carbohydrate and protein-rich spice. The low fat content does not qualify garlic as an oil plant; however, the oil can be extracted for use as essence or essential oil (Okwu and Nnamdi, 2008). Dashak et al. (2001) explained that the high crude protein content of garlic was due to the presence of active proteinous metabolites such as allicin, ajoene and capsaicin. The normal daily protein requirement for a normal adult is 45 to $50 \mathrm{~g}$, therefore, the value at 15.33 $\mathrm{mg} / 100 \mathrm{~g}$ obtained suggests that garlic can serve as protein supplement in human main dishes. The low level of crude fibre at $2.10 \mathrm{mg} / 100 \mathrm{~g}$ poses no threat since garlic is usually consumed as adjunct or additive to other foods. The low moisture content in the dry matter shows that garlic will have long shelf life and with limited deterioration due to microbial contamination as earlier reported by Dashak et al. (2001).

The results obtained in this study agree with the report of Otunola et al. (2010) that the moisture, crude protein, crude fat, total carbohydrates, fibre and ash contents in garlic were $4.55 \pm 0.1,15.33,0.72,73.22,2.10$ and $4.08 \%$, respectively on dry matter basis. The values obtained in this study were slightly lower than the values reported for moisture and crude protein at 4.88 and $17.35 \%$ respectively by Nwinuka et al. (2005) and similar to the values of $73.03,0.68,4.06 \%$ reported for carbohydrate, crude fat and ash contents, respectively by the same authors. Also, the proximate composition of garlic in this study showed values that were slightly lower than the values of 5.4, 17.5 and $73.3 \%$ reported in Encyclopedia of Chemical Technology (1980) for moisture, protein and total carbohydrate. 
Table 1. Proximate composition of garlic powder.

\begin{tabular}{lc}
\hline Nutrients & Composition $(\mathbf{m g} / \mathbf{1 0 0 g})$ \\
\hline Moisture content & 4.55 \\
Crude protein & 15.33 \\
Crude fat & 0.72 \\
Crude fibre & 2.10 \\
Ash & 4.08 \\
Carbohydrate & 73.22 \\
\hline
\end{tabular}

Table 2. Mineral composition of garlic on dry matter basis.

\begin{tabular}{lc}
\hline Mineral elements & Concentration $(\mathbf{m g} / \mathbf{1 0 0 g}))$ \\
\hline Potassium & 10.19 \\
Calcium & 26.30 \\
Phosphorus & 10.19 \\
Iron & 5.29 \\
Magnesium & 0.001 \\
Zinc & 0.34 \\
Manganese & 0.001 \\
Lead & Nil \\
Cobalt & Nil \\
\hline
\end{tabular}

However, the result disagrees with the reports of $\mathrm{Bi}$ and Usha (2016) who reported that garlic contains $3.91 \%$ moisture, $19.75 \%$ protein, $0.49 \%$ Fat, $1.73 \%$ crude fibre, $66.36 \%$ carbohydrate and $3.39 \%$ total ash on dry matter basis. Also, the results disagree with the findings of Odebunmi et al. (2009) who concluded that garlic contains $66.57,7.87,0.52,0.73,1.33$ and $33.43 \%$ of moisture, protein, fat, crude fibre, ash and dry matter, respectively and the report of Marina et al. (2014) that garlic contains $64.58 \%$ moisture, $7.87 \%$ protein, $0.52 \%$ ether extract, $2.3 \%$ fibre, $2.46 \%$ ash and $22.27 \%$ Nitrogen Free Extract.

The mineral analysis of garlic is presented in Table 2. The results indicated high values in potassium $(K)$, calcium $(\mathrm{Ca})$, phosphorus $(\mathrm{P})$ and iron $(\mathrm{Fe})$ compared to magnesium $(\mathrm{Mg})$, zinc $(\mathrm{Zn})$ and manganese $(\mathrm{Mn})$ which were found in trace forms. Garlic contained 10.19, 26.30, $10.19,5.29,0.001,0.34$ and $0.001 \mathrm{mg} / 100 \mathrm{~g}$ of potassium, calcium, phosphorus, iron, magnesium, zinc and manganese respectively while lead and cobalt were below detection level. Low ash is an indication of low inorganic mineral content (Oloyede, 2005) but garlic contained appreciable amounts of mineral elements which make garlic a potential regulator of blood pressure, fluid balance, anti-hypertension, anti-cardiac arrhythmias, anti-ischemic heart disease, anti-atherogenesis, anti-sudden cardiac death, anti-diabetic and essential in bone and teeth formation (Karppanen, 1994). Garlic has important functions in the control of arterial resistance (Altura and Altura, 1999) and regulation of fluid balance in the body such that it influences the cardiac output. Below normal dietary intake of $\mathrm{Mg}$ has been identified as a strong risk factor for hypertension, cardiac arrhythmias, ischemic heart disease, atherogenesis and sudden cardiac death (Altura and Altura, 1999). Zinc (Zn) and Chromium (Cr) are co-factors for insulin which makes garlic relevant to treatment of diabetes (Kimura, 1996) while $\mathrm{Ca}, \mathrm{Mg}$ and $\mathrm{P}$ are essential for bone and teeth formation (Okwu, 2005). The non-detection of $\mathrm{Pb}$ and $\mathrm{Co}$ is of great advantage to consumers of garlic as these elements can be highly toxic even at low concentrations (Asaolu et al., 1997; Oloyede, 2005). Extremely lower potassium was obtained compared to $54.00 \mathrm{mg} / 100 \mathrm{~g}$ reported by Otunola et al. (2010). The calcium and phosphorus contents of garlic were clearly lower than the values of 54.65 and $10.19 \mathrm{mg} / 100 \mathrm{~g}$, respectively obtained by Marina et al. (2014) and also higher than $1.904 \mathrm{mg} / 100 \mathrm{~g}$ obtained by Ujowundu et al. (2011) in calcium but similar to $26.30 \mathrm{mg} / 100 \mathrm{~g}$ calcium, $10.19 \mathrm{mg} / 100 \mathrm{~g}$ phosphorus, $5.29 \mathrm{mg} / 100 \mathrm{~g}$ iron and 0.001 $\mathrm{mg} / 100 \mathrm{~g}$ manganese obtained by Otunola et al. (2010). Marina et al. (2014) obtained $9.54 \mathrm{mg} / 100 \mathrm{~g}$ iron which was higher than the value obtained in this study and Ujowundu et al. (2011) obtained a lower value of $3.59 \mathrm{mg} / 100 \mathrm{~g}$. The probable reason for this wide variation in the mineral contents could be attributed to differences in the fertility of the soil from which the garlic were cultivated or human error.

Table 3 shows the phytochemical properties of garlic powder. Garlic is acidic $(\mathrm{pH}=3.91)$ and contained 4.21, $3.54,0.64,0.80,5.56,0.04$ and $0.02 \mathrm{mg} / 100 \mathrm{~g}$ of alkaloids, tannins, carotenoids, saponin, flavonoids, steroids and cardenolides, respectively. Phytochemicals are bioactive, non-nutrient, naturally-occurring plant compounds found in vegetables, fruits and spices (Okarter et al., 2009). Purified alkaloids and their synthetic derivatives are medicinal agents as analgesic, anti-malarial, antiseptic and bactericidal (Evans et al., 2002). The high alkaloid content in garlic dry matter is probably responsible for its muchacclaimed medicinal values. Saponins are produced by plants as a defence mechanism to stop attacks by foreign pathogens which make them natural antibiotics (Okwu and Emenike, 2006). They also have cholesterol lowering effects and are able to kill or inhibit cancer cells (Okwu, 2005; Nwinuka et al., 2005; Okwu and Emenike, 2006; Okwu and Nnamdi, 2008). Therefore, the appreciable amount of saponins in garlic could be responsible for its antimicrobial properties. The presence of tannins might have accounted for the sharp taste of garlic and ability to hasten the healing of wounds and inflamed mucous membranes (Okwu and Emenike, 2006). Cardenolides contribute to the medicinal values of plants in which they occur and have been known for the treatment of congestive heart failure (Oloyede, 2005). Flavonoids protect against allergies, inflammation, platelet aggregation and microbial infection (Okwu and Omodimiro, 2005). Carotenoids are largely responsible for 
Table 3. Percentage composition of phytochemicals in garlic powder.

\begin{tabular}{|c|c|}
\hline Garlic Phytochemical & Composition \\
\hline Alkaloids (mg100g-1) & 4.21 \\
\hline Tannins $\left(\mathrm{mg}^{100 \mathrm{~g}^{-1}}\right)$ & 3.54 \\
\hline Carotenoids $\left(\mu \mathrm{g} 100 \mathrm{~g}^{-1}\right)$ & 0.64 \\
\hline Saponin $\left(\mathrm{mg} 100 \mathrm{~g}^{-1}\right)$ & 0.80 \\
\hline Flavonoids $\left(\mathrm{mg}^{100 \mathrm{~g}^{-1}}\right)$ & 5.56 \\
\hline Steroids (mg100g-1) & 0.04 \\
\hline Cardenolides $\left(\mathrm{mg}^{100 \mathrm{~g}^{-1}}\right)$ & 0.02 \\
\hline $\mathrm{pH}$ & 3.91 \\
\hline Titratable acidity (\% as lactic acid) & 0.97 \\
\hline Salt $(\% \mathrm{NaCl})$ & 2.39 \\
\hline
\end{tabular}

the colour of garlic (Tripathi and Mishap, 2009). In general, the presence of these phytochemicals account for the much-touted medicinal properties of garlic in various disease conditions such as atherosclerosis, arthritis, nausea, asthma, bacterial infections and cancer (Das and Saha, 2008; Kaur and Arora, 2009).

In conclusion, garlic is rich in protein, alkaloids, tannin and flavonoids and has an acidic $\mathrm{pH}$ of 3.91. The moisture content is low with trace amounts of carotenoids, saponin, steroids and cardenolides. It has appreciable mineral components but lead and cobalt were not detected.

\section{CONFLICT OF INTEREST}

The authors declare that they have no conflict of interest.

\section{REFERENCES}

Altura, B. M., \& Altura, B. T. (1999). Cardiovascular risk factors and magnesium: relationship to atherosclerosis, ischemic heart disease and hypertension. Indian J. Exp. Biol. 37(2), 109116

AOAC (2000). Official methods of analysis of AOAC. International $17^{\text {th }}$ edition; Gaithersburg, MD, USA Association of Analytical Communities.

Asaolu, S. S., Ipinmoroti, C. E., Adeyinwo, C. E., \& Olaofe, O. (1997). Seasonal variation in heavy metal distribution in sediment of Ondo state coastal region. Ghana J. of Chem., 3, 11-16.

Boham, B. A., \& Kocipai-Abyazan, R. (1994). Flavonoids and condensed tannins from leaves of Hawaiian Vaccinium vaticulatum and V. calycynium. Pac. Sci., 48, 458-463.

Borek, C. (2005). Antioxidants and the prevention of hormonally regulated cancer. The J. Mens Health Gender, 2, 346-52.

Chowdhury, S. R., Chowdhury, S. D., \& Smith, T. K. (2002). Effect of dietary garlic on cholesterol metabolism in laying hen. Journal of Poultry Science, 7(2), 122-128.

Das, I., \& Saha, T. (2008). Effect of garlic on lipid peroxidation and antioxidation enzymes in DMBA induced skin carcinoma. Nutrition, 25(4), 459-471.
Dashak, D. A., Dawang, M. L., \& Lucas, N. B. (2001). An assessment of the proximate composition of locally produced spices known as dadawa basso and dadawa kawla from three markets in Plateau State of Nigeria. Food Chem., 75(2), 231235.

Dilhuydy, J. M. (2003). Patients attraction to complementary and alternative medicine (CAM): a reality which physicians can neither ignore nor deny. Bull. on cancer, 90, 623-628.

Durak, I., Oztürk, H. S., Olcay, E., \& Güven, C. (2002). Effects of garlic extract supplementation on blood lipid and antioxidant parameters and atherosclerotic plaque formation process in cholesterol-fedrabbits. J. Herb Pharmacother. 2, 19-32.

Encyclopedia of Chemical Technology (1980) Encyclopedia of Chemical Technology, 3rd edn. John Wiley and Sons, New York. Vol. 10, Pp. 477-480.

Evans, M., Roberts, A., \& Rees, A. (2002). The future direction of cholesterol-lowering therapy. Curr. Opin Lipidol, 13, 663-669.

Friday, O., Uhegbu, I., Emek, E., Iweala, J., \& Ijeoma, K. (2011). Studies on the chemical and antinutritional content of some Nigerian spices. International Journal of Nutrition and Metabolism, 3(6), 72-76.

Harbone, J. B. (1973). Phytochemical Methods: A Guide to Modern Techniques in Plants Analysis. Chapman and Hall, London, IDRC Publication, 154p.

Heinrich, M., Barnes, J., Gibbsons, S., \& Williamson, M. E. (2004). Fundamentals of Pharmacognosy and PhytotherapyA Textbook. Churchil Livingstone, U.K. Pp. 32-221.

Iwalokun, B. A., Ogunledun, A., Ogbolu, D. O., Bamiro, S. B., \& Jimi-Omojola, J. (2004). In vitro antimicrobial properties of aqueous garlic extract against multidrug-resistant bacteria and Candida species from Nigeria. J. Med. Food, 7(3), 327-333.

Jennifer, H. (2002). Garlic Supplements Longwood Herbal Task force. Available

at www.ukmi.nhs.ukmedinto/docuents/garlicsuppsemsfinal 2.pdf.

Karppanen, H. (1994). Minerals and blood pressure. Environ. Health Persp., 102(suppl.7), 65-72.

Kaur, G. J., \& Arora, D. S. (2009). Antibacterial and phytochemical screening of Anethum graveolens, foeniculum vulgare and Trachyspermum ammi. BMC Compl. Alt. Med., 9, 30.

Kimura, K. (1996). Role of essential trace elements in the disturbance of carbohydrate metabolism. Nippon-Rinsho, 54(1), 79-84

Kishu, T. (2009). A Review -Garlic, the Spice of Life-(Part-I). Asian Journal of Research in Chemistry, 2(1), 8-13.

Lewis, M. R., Rose, S. P., Mackenzie, A. M., \& Tucker, L. A. (2008). Effects of dietary inclusion of plant extracts on the growth performance of male broiler chickens. Brit. Poult. Sci., 44 (Suppl.), 43.

Marina, S., Butt, M. S., Masood, B., Shehzad, A., \& Tanweer, S. (2014). Chemical and mineral analysis of garlic: a golden herb. Pakistan Journal of Food Sciences, 24(1), 108-110.

Nwinuka, N. M., Ibeh, G. O., \& Ekeke G. I. (2005). Proximate composition and levels of some toxicants in four commonly consumed spices. J. Appl. Sci. Environ. Manage., 9(1), 150155.

Odebunmi, E. O., Oluwaniyi, O. O., \& Bashiru, M. O. (2009). Comparative proximate analysis of some food condiments. J. App. Sci. Res., 2(1), 1-3.

Okaka, J. C., \& Okaka, A. N. O. (2001). Food composition, spoilage and shelf-life extension. Ociarco Academic 
publishers, Enugu, Nigeria. Pp. 54-66.

Okarter, N., Liu, C. C., Sorrells, M. E., \& Liu, R. H. (2009). Phytochemical content and antioxidant activity of six diverse varieties of whole wheat. Food Chem., 119(1), 249-257.

Okwu, D. E. (2005). Phytochemical, vitamins and mineral contents of two Nigerian medicinal plants. Int. J. Mol. Med. Adv. Sci., 1, 375-381.

Okwu. D. E., \& Omodamiro, D. O. (2005). Effect of Hexane extract and phytochemical content of xylopia aethiopica and Ocimum gratissimum on uterus of guinea pig. Bio-Res., 3(2), 40- 44.

Okwu, D. E., \& Nnamdi F. U. (2008). Evaluation of the chemical composition of Dacryodes edulis and Raphia hookeri Mann and Wendl exudates used in herbal medicine in South Eastern Nigeria. Afr. J. Trad. Comp. Alt. Med., 5(2), 194-200.

Okwu, D. E., \& Emenike, I. N. (2006). Evaluation of the phytonutrients and vitamin contents of citrus fruits. Int. J. Mol. Med. Adv. Sci., 2(1), 1-6.

Oloyede, O. I. (2005). Chemical profile of unripe pulp of Carica papaya. Pak. J. Nutr. 4(6), 379-381.

Otunola, G. A., Oloyede, O. B., Adenike, T., Oladiji, T., \& Afolayan, A. J. (2010). Comparative analysis of the chemical composition of three spices Allium sativum, Zingiber officinale Rosc. and Capsicum frutescens L. commonly consumed in Nigeria. Afr. J. Biotechnol., 9(41), 6927-6931.
Shalaby, A. M., Khattab, Y. A., \& Abdel Rahman, A. M. (2006). Effects of garlic (Allium sativum) and chloramphenicol on growth performance, physiological parameters and survival of nile tilapia (Oreochromis niloticus). J. Venomous Anim. Toxins Incl. Trop. Dis., 12, 172-201.

Topak, R., Süeri, S., \& Çalişir, S. C. (2005). Investigation of the energy efficiency for raising crops under sprinkler irrigation in a semi-arid area. Applied Engineering in Agriculture, 21(5), 761-768.

Tripathi, S., \& Mishra, H. N. (2009). Nutritional changes in powdered red pepper upon in vitro infection of Aspergillus flavus. Braz. J. Microbiol., 40(1), 139-144

Ujowundu, C. O., Kalu, F. N., Nwosunjoku, E. C., Nwaoguikpe, R. N., Okechukwu, R. I., \& Igwe, K. O. (2011). lodine and inorganic mineral contents of some vegetables, spices and grains consumed in Southeastern Nigeria. Afri. J. Biochem. Res., 5(2), 57-64. 